Article

\title{
Chemical Composition, Antioxidant and Antihyperglycemic Activities of the Wild Lactarius deliciosus from China
}

\author{
Zhou Xu ${ }^{1,+}$, Liang Fu ${ }^{2,+}$, Shiling Feng ${ }^{1}$, Ming Yuan ${ }^{1}$, Yan Huang ${ }^{1}$, Jinqiu Liao ${ }^{1}$, Lijun Zhou ${ }^{1}$, \\ Hongyu Yang ${ }^{1}$ and Chunbang Ding ${ }^{1, *}$ \\ 1 College of Life Sciences, Sichuan Agricultural University, Yaan 625014, China; xzhsicau@163.com (Z.X.); \\ fengshilin@outlook.com (S.F.); yuanming@sicau.edu.cn (M.Y.); shirley11hy@163.com (Y.H.); \\ liaojinqiu630@sicau.edu.cn (J.L.); zhouzhou124@126.com (L.Z.); yhy4868135@163.com (H.Y.) \\ 2 Dazhou Institute of Agricultural Sciences, Dazhou 635000, China; fuliangrain@126.com \\ * Correspondence: dcb@sicau.edu.cn; Tel.: +86-083-562-5014 \\ + These authors contributed equally to this paper.
}

Academic Editors: Alessandra Gentili and Chiara Fanali

Received: 13 March 2019; Accepted: 1 April 2019; Published: 6 April 2019

check for updates

\begin{abstract}
The wild mushroom Lactarius deliciosus from China was studied for the first time to obtain information about its chemical composition, antioxidant, and antihyperglycemic activities. Nutritional value, dietary fiber, fatty acids, metal elements, free sugars, free amino acids, organic acids, flavor 5'-nucleotides, and volatile aroma compounds were determined. Potential antioxidant and antihyperglycemic activities were also tested by investigating 1,1-diphenyl-2-picrylhydrazyl (DPPH) and 2,2'-Azino-bis(3-ethylbenzothiazoline-6-sulfonic acid) (ABTS) radicals scavenging activities, ferric ion reducing activity, as well as $\alpha$-amylase and $\alpha$-glucosidase inhibitory activities using ethanol and aqueous extracts. The results showed that L. deliciosus was a good wild mushroom with high protein, carbohydrate, and dietary fiber contents, while low in fat and calorie, extensive unsaturated fatty acids contents, with negligible health risks about harmful metal elements. Twenty kinds of free amino acids were detected with a total content $3389.45 \mathrm{mg}$ per $100 \mathrm{~g} \mathrm{dw}$. Flavor $5^{\prime}$-nucleotides including 5'-CMP, 5'-UMP, 5'-IMP, and 5'-AMP were 929.85, 45.21, 311.75, and $14.49 \mathrm{mg}$ per $100 \mathrm{~g} \mathrm{dw}$, respectively. Mannitol (7825.00 mg per $100 \mathrm{~g} \mathrm{dw}$ ) was the main free sugar, and quininic acid (729.84 $\mathrm{mg}$ per $100 \mathrm{~g} \mathrm{dw}$ ) was the main organic acid. Twenty-five kinds of volatile aroma compounds were identified, acids (84.23\%) were the most abundant compounds based on content, while aldehydes (15 of 25) were the most abundant compounds based on variety. In addition, both ethanol and aqueous extracts from $L$. deliciosus exhibited excellent antioxidant activity. While in antihyperglycemic activity tests, only ethanol extracts showed inhibitory effects on $\alpha$-amylase and $\alpha$-glucosidase.
\end{abstract}

Keywords: Lactarius deliciosus; chemical composition; antioxidant; antihyperglycemic

\section{Introduction}

Edible mushrooms consist of Basidiomycota and Ascomycota members [1]. Abundant protein, essential amino acids, mineral elements, dietary fiber, flavor 5'-nucleotides, and volatile aroma components endowed mushrooms with great nutritional value and unique flavor [2,3]. Thus, mushrooms have been consumed as popular food stuff and flavoring for centuries, and consumer demand has continued to increase in recent years. Nowadays, dozens of cultivated mushrooms such as Agaricus bisporus, Lentinula edodes, Pleurotus ostreatus, Flammulina velutipes, and Auricularia auricula occupy the main consumer market, but there are far more mushrooms that cannot be artificially cultivated called wild mushrooms that only come from field acquisition [4,5]. Although difficult 
to collect, wild mushrooms are still pursued by innumerable gluttons due to their unique flavors, and Tuber melanosporum, Tricholoma matsutake and Collybia albuminosa, etc., are regarded as gems [6,7]. Moreover, in the east, traditional medicine theory holds the concept that "drug homologous food", hence, mushrooms also serve as indispensable raw materials for pharmaceuticals [8].

Lactarius Persoon is an ectomycorrhizal group belonging to the family of Russulaceae and widespread in temperate, subtropical and tropical forests. To date, $\sim 500$ species of Lactarius Per. have been discovered around the world and Lactarius deliciosus is one of them [9]. Owing to its excellent taste, texture, and flavor, L. deliciosus is popular in China, with some chemical substances and bioactivities of L. deliciosus being reported. Research has shown that sesquiterpenoids contribute to the unique color of L. deliciosus, some of which possess potent biological activities such as antimicrobial and anticancer [10-12]. Ding et al. and Hou et al. reported that L. deliciosus polysaccharides exhibited significant anti-tumor activity in mice in vivo and immunomodulatory effects through proliferative growth of both B cell and macrophages cell in vitro [13,14]. Meanwhile, other L. deliciosus extracts also have various biological activities such as enzymes inhibition, antioxidant, antimicrobial, and anti-inflammatory [15-17].

As an essential class of food raw material, the nutritional value of mushrooms is comprehensively decided by proteins, carbohydrates, fats, minerals, etc., and this is crucial consumer focus point [18]. Other factors such as free sugars, free amino acids, organic acids, flavor 5 '-nucleotides, and volatile aroma components could dramatically affect taste and flavor, and should not be ignored $[19,20]$. In China, although L. deliciosus is a popular wild edible mushroom, comprehensive studies of this fungi are relatively lacking. Based on the above, we collected wild L. deliciosus from Sichuan Province (South-west of China), and chemical compositions including proteins, carbohydrates, fats, dietary fiber, minerals, free sugars, free amino acids, organic acids, flavor $5^{\prime}$-nucleotides, and volatile aroma components were analyzed. In addition, we evaluated bioactivities by assaying antioxidant and anti-hyperglycemic activities of ethanol and aqueous extracts.

\section{Results and Discussion}

\subsection{General Nutritional Value}

Generally, mushrooms are considered as a valuable health food since they have perfect proportions of protein, fat, and carbohydrate. As summarized in Table 1, fresh L. deliciosus was preponderantly moist, and dry matter content was relatively low (8.00\%). This result was in accordance with previous studies demonstrating that dry weight content of fresh mushrooms was generally $5-15 \%$ [21,22]. In the dried fruiting body, carbohydrate was the most abundant substance with $66.61 \mathrm{~g}$ per $100 \mathrm{~g} \mathrm{dw}$, followed by protein (17.19 g per $100 \mathrm{~g} \mathrm{dw})$, ash ( $8.62 \mathrm{~g}$ per $100 \mathrm{~g} \mathrm{dw})$, and fat (4.82 per $100 \mathrm{~g} \mathrm{dw})$. Moreover, $31.81 \mathrm{~g}$ per $100 \mathrm{~g} \mathrm{dw}$ total dietary fiber was detected in L. deliciosus, indicating that consuming this mushroom is a great way for dietary fiber intake. On the whole, L. deliciosus is a good food that can meet the low-calorie requirements. 
Table 1. Proximate composition, energetic value, dietary fiber, and fat composition of wild L. deliciosus.

\begin{tabular}{cc}
\hline Component & L. deliciosus \\
\hline Moisture $(\mathrm{g}$ per $100 \mathrm{~g})$ & $92.00 \pm 0.64$ \\
Dry matter $(\mathrm{g}$ per $100 \mathrm{~g})$ & $8.00 \pm 0.64$ \\
Total carbohydrate (g per $100 \mathrm{~g} \mathrm{dw})$ & $66.61 \pm 1.02$ \\
Crude fat $(\mathrm{g}$ per $100 \mathrm{~g} \mathrm{dw})$ & $4.82 \pm 0.15$ \\
Crude Protein (g per $100 \mathrm{~g} \mathrm{dw})$ & $17.19 \pm 0.06$ \\
Ash (g per $100 \mathrm{~g} \mathrm{dw})$ & $8.62 \pm 0.25$ \\
Energy (kcal per $100 \mathrm{~g} \mathrm{dw})$ & $378.60 \pm 2.74$ \\
Total dietary fiber (g per 100 g dw) & $31.81 \pm 1.51$ \\
Insoluble dietary fiber (g per 100 g dw) & $26.51 \pm 1.54$ \\
Soluble dietary fiber (g per 100 g dw) & $5.30 \pm 0.36$ \\
C16:0 (\% of total fatty acids) & $5.17 \pm 0.30$ \\
C18:0 (\% of total fatty acids) & $16.96 \pm 0.19$ \\
C18:1 (\% of total fatty acids) & $48.37 \pm 0.62$ \\
C18:2 (\% of total fatty acids) & $29.49 \pm 0.55$ \\
\hline
\end{tabular}

Four fatty acids were identified in the crude fat and their constituents were as follows: palmitic acid (C16:0, 5.17\%), stearic acid (C18:0, 16.96\%), oleic acid (C18:1, 48.37\%), and linoleic acid (C18:2, 29.49\%) (Table 1 and Figure S1). Unsaturated fatty acids (C18:1 and C18:2) were dominant in L. deliciosus fat, which was in agreement with previous research on wild edible mushrooms [23,24]. Moreover, recent research has documented that unsaturated fatty acids may lower the risk of cardiovascular disease, type two diabetes, and cancer $[25,26]$. Nevertheless, considering the low level of fat in L. deliciosus, the health effects of various fatty acids are very limited.

Compared to green plants, the metal content in mushrooms is higher due to their effective mechanism of easily accumulating metals from the ecosystem [27]. Thus, wild edible mushrooms are regarded as an excellent choice for dietary mineral requirement. Concurrently, a hidden danger is arising with excess heavy metal ingestion. As summarized in Table 2, magnesium and calcium contents of L. deliciosus were 1244.29 and $247.07 \mathrm{mg}$ per $\mathrm{kg} \mathrm{dw}$, this result was in agreement with a previous conclusion that calcium content in mushrooms is $100-500 \mathrm{mg} / \mathrm{kg} \mathrm{dw}$, and magnesium is $800-1800 \mathrm{mg}$ per $\mathrm{kg} \mathrm{dw}$, based on data collected from over 1000 samples of 400 mushroom species [28]. Among trace elements, iron content (197.01 mg per $\mathrm{kg} \mathrm{dw}$ ) was notably the highest. Of note, compared with numerous studies, copper content $(1.28 \mathrm{mg}$ per $\mathrm{kg} \mathrm{dw}$ ) in this sample was relatively low, which might be related to the physiological property of this species due to L. deliciosus always possessing lower copper content in other comparative studies [29,30]. Usually, daily intake is $300 \mathrm{~g}$ of fresh mushroom, which contains $\sim 30 \mathrm{~g}$ of dry matter [31]. Compared with recommended dietary allowance (RDA) and adequate intake (AI) for females and males (aged from 19 to 30) recommended by the Institute of Medicine, consumption of L. deliciosus does not provide significant contribution to calcium and copper supplementation, while good contribution of magnesium, zinc, manganese, iron, and chromium [32,33]. Notably, although a large daily intake value of chromium was observed (up to $344.57 \%$ for male and $482.40 \%$ for female of $\mathrm{AI} \%$ ), this poses no risk to the human body, with reference to the tolerable upper intake level recommended by the Institute of Medicine [33]. Moreover, toxic arsenic, cadmium, and plumbum were also detected in L. deliciosus. EU scientific committee standards stipulated provisional tolerable daily intake values for arsenic, cadmium, and plumbum for adults (of $60 \mathrm{~kg}$ body weight) were $0.13,0.06$, and $0.21 \mathrm{mg}$, respectively. Therefore, the intake of heavy metals (arsenic, cadmium, and plumbum) via consuming L. deliciosus is risk-free for the consumers. 
Table 2. Contents and daily intake estimations of metal elements of wild L. deliciosus.

\begin{tabular}{|c|c|c|c|c|c|c|}
\hline \multirow{2}{*}{ Element } & \multirow{2}{*}{$\begin{array}{c}\text { Content } \\
(\mathrm{mg} \text { per } \mathrm{kg} \mathrm{dw})\end{array}$} & \multirow{2}{*}{$\begin{array}{l}\text { Daily Intake } \\
\text { (mg/day) }^{a}\end{array}$} & \multicolumn{2}{|c|}{ RDA or AI (mg/d) d } & \multicolumn{2}{|c|}{ RDA or AI $\%^{d}$} \\
\hline & & & Male & Female & Male & Female \\
\hline Magnesium & $1244.29 \pm 42.16$ & 37.33 & $400^{b}$ & $310^{b}$ & 9.33 & 12.04 \\
\hline Calcium & $247.07 \pm 4.23$ & 7.41 & $1000^{\mathrm{c}}$ & $1000^{c}$ & 0.74 & 0.74 \\
\hline Zinc & $52.34 \pm 2.68$ & 1.57 & $11^{b}$ & $8^{b}$ & 14.28 & 19.63 \\
\hline Manganese & $23.12 \pm 0.75$ & 0.69 & $2.3^{c}$ & $1.8^{\mathrm{c}}$ & 30.16 & 38.53 \\
\hline Iron & $197.01 \pm 13.14$ & 5.91 & $8^{b}$ & $18^{b}$ & 73.88 & 32.84 \\
\hline Chromium & $4.02 \pm 0.69$ & 0.12 & $0.035^{c}$ & $0.025^{c}$ & 344.57 & 482.40 \\
\hline Copper & $1.28 \pm 0.02$ & 0.04 & $0.9^{b}$ & $0.9^{\mathrm{b}}$ & 4.27 & 4.27 \\
\hline Arsenic & $0.75 \pm 0.04$ & 0.02 & - & - & - & - \\
\hline Cadmium & $1.91 \pm 0.05$ & 0.06 & - & - & - & - \\
\hline Plumbum & $0.85 \pm 0.04$ & 0.03 & - & - & - & - \\
\hline
\end{tabular}

${ }^{a}$ Daily element intake values calculated using $30 \mathrm{~g}$ L. deliciosus dry matter; ${ }^{\mathrm{b}}$ RDA recommended by the Institute of Medicine; ${ }^{\mathrm{C}} \mathrm{AI}$ recommended by the Institute of Medicine; ${ }^{\mathrm{d}} \mathrm{RDA}$ or AI for both males and females aged 19-30; - Toxic elements without RDA and AI.

\subsection{Non-Volatile Compounds Relating to Special Flavour}

Edible mushrooms are considered a valuable food for their abundance of nutrients and desirable complex delicious taste. The taste of mushrooms is primarily ascribed to abundant soluble non-volatile taste components, such as free amino acids, flavor $5^{\prime}$-nucleotides, free sugars, and organic acids $[34,35]$. As shown in Table 3 and Figure S2, twenty-two kinds of amino acids have been measured, of which, twenty kinds were found in the free amino acids of L. deliciosus, and the content of total free amino acids (TAA) was $3389.45 \mathrm{mg}$ per $100 \mathrm{~g} \mathrm{dw}$. Among these amino acids, glutamic acid, glutamine, histidine, and alanine were found in relatively high concentrations. Moreover, the content of nine kinds of essential amino acids (EAA) in L. deliciosus was $1026.29 \mathrm{mg}$ per $100 \mathrm{~g} \mathrm{dw}$, accounting for $30.28 \%$ of total free amino acids. This proportion was approximate to a previous report by Sun et al., in which they found the ratios of EAA/TAA in Tricholomopsis lividipileata, Boletinus pinetorus, and Amanita hemibapha were $26.82,27.94$, and $34.75 \%$, respectively [36]. Free amino acids can be classified into four groups based on their taste characteristics. Aspartic acid and glutamic acid were monosodium glutamate-like (MSG-like) components responsible for umami taste. The level of MSG-like free amino acids in L. deliciosus was $415.71 \mathrm{mg}$ per $100 \mathrm{~g} \mathrm{dw}$, which was at low-level ( $<500 \mathrm{mg}$ per $100 \mathrm{~g} \mathrm{dw}$ ) of MSG-like components according to the standard defined by Yang et al. [37]. Threonine, serine, glycine, and alanine were sweet taste amino acids, amounting to $734.82 \mathrm{mg}$ per $100 \mathrm{~g} \mathrm{dw}$. Valine, methionine, isoleucine, leucine, phenylalanine, histidine, arginine, tryptophan, and tyrosine were classified as bitter amino acids. In L. deliciosus, the amount of bitter amino acids was $1033.29 \mathrm{mg}$ per $100 \mathrm{~g} \mathrm{dw}$. Although bitter amino acids might bring bitterness, while sweet taste amino acids and soluble sugars could mask this unpleasant taste. Asparagine, glutamine, citrulline, proline, and lysine did not have effects on taste.

The chromatograms concerning flavor 5'-nucleotides, free sugars, and organic acids are presented in Figures S3-S5, and the compositions of these components are summarized in Table 4. The amount of total flavor $5^{\prime}$-nucleotides in L. deliciosus was $1301.30 \mathrm{mg}$ per $100 \mathrm{~g} \mathrm{dw}$, and the individual contents of 5'-CMP, 5'-UMP, 5'-IMP, and 5'-AMP were 929.85, 45.21, 311.75, and $14.49 \mathrm{mg}$ per $100 \mathrm{~g} \mathrm{dw}$, respectively, while $5^{\prime}$-GMP and $5^{\prime}$-XMP were not detected. Based on the amount of total flavor $5^{\prime}$-nucleotides, Yang et al. divided flavor $5^{\prime}$-nucleotides into three ranges, low ( $<100 \mathrm{mg}$ per $100 \mathrm{~g} \mathrm{dw}$ ), medium (100-500 mg per $100 \mathrm{~g} \mathrm{dw}$ ), and high (>500 mg per $100 \mathrm{~g} \mathrm{dw}$ ) [37]. Accordingly, the amount of flavor $5^{\prime}$-nucleotides in L. deliciosus fell within the high category. Regarding free sugars, trehalose and mannitol have been detected, and their contents were 4990.09 and $7825.00 \mathrm{mg}$ per $100 \mathrm{~g} \mathrm{dw}$, respectively. Compared with other wild mushrooms, the content of total free sugars in L. deliciosus was in the mid range, which would contribute a moderate sweet taste perception [38-40]. In the context of organic acids, quininic acid predominated in L. deliciosus, followed by L-malic acid and fumaric acid. 
Oxalic acid was not found in L. deliciosus in this study, in which was however identified in another report of L. deliciosus from Portugal [41].

Table 3. Free amino acids composition of wild L. deliciosus.

\begin{tabular}{|c|c|}
\hline Free Amino Acid & Content (mg per $100 \mathrm{~g} \mathrm{dw})$ \\
\hline Aspartic acid ${ }^{b}$ & $39.43 \pm 0.87$ \\
\hline Glutamic acid $^{\mathrm{b}}$ & $376.29 \pm 4.12$ \\
\hline Asparagine & $79.41 \pm 0.84$ \\
\hline Serine ${ }^{c}$ & $136.35 \pm 0.66$ \\
\hline Glutamine & $794.06 \pm 54.85$ \\
\hline Histidine ${ }^{a, d}$ & $278.57 \pm 23.62$ \\
\hline Glycine $^{c}$ & $91.32 \pm 0.59$ \\
\hline Threonine ${ }^{a, c}$ & $131.76 \pm 3.45$ \\
\hline Citrulline & $16.26 \pm 0.59$ \\
\hline Arginine $^{d}$ & $155.70 \pm 11.34$ \\
\hline Alanine ${ }^{c}$ & $375.38 \pm 2.59$ \\
\hline Tyrosine $^{\mathrm{d}}$ & $91.53 \pm 1.38$ \\
\hline Cystine & - \\
\hline Valine $^{\mathrm{a}, \mathrm{d}}$ & $122.17 \pm 4.93$ \\
\hline Methionine $^{\mathrm{a}, \mathrm{d}}$ & $25.41 \pm 0.62$ \\
\hline Tryptophan ${ }^{a, d}$ & $68.95 \pm 0.43$ \\
\hline Phenylalanine ${ }^{a, d}$ & $133.61 \pm 0.45$ \\
\hline Isoleucine ${ }^{\mathrm{a}, \mathrm{d}}$ & $47.82 \pm 0.95$ \\
\hline Leucine ${ }^{a, d}$ & $109.53 \pm 1.61$ \\
\hline Lysine $^{a}$ & $208.46 \pm 16.92$ \\
\hline Hydroxyproline & - \\
\hline Proline & $107.43 \pm 12.44$ \\
\hline Total free amino acids (TAA) & $3389.45 \pm 38.13$ \\
\hline
\end{tabular}

a Essential amino acids; ${ }^{\mathrm{b}}$ Monosodium glutamate-like (MSG-like) amino acids; ${ }^{\mathrm{c}}$ sweet amino acids; ${ }^{\mathrm{d}}$ bitter amino acids; - Not detected.

Table 4. Flavor $5^{\prime}$-nucleotides, free sugars and organic acids composition of wild L. deliciosus.

\begin{tabular}{cc}
\hline Component & Content $(\mathbf{m g}$ per $\mathbf{1 0 0} \mathbf{g ~ d w})$ \\
\hline 5'-CMP & $929.85 \pm 42.33$ \\
5'-UMP & $45.21 \pm 6.72$ \\
5'-IMP & $311.75 \pm 13.43$ \\
5'-AMP & $14.49 \pm 3.37$ \\
Trehalose & $4990.09 \pm 307.95$ \\
Mannitol & $7825.00 \pm 466.72$ \\
Quininic acid & $729.84 \pm 71.80$ \\
L-Malic acid & $415.63 \pm 87.44$ \\
Fumaric acid & $120.71 \pm 11.45$ \\
\hline
\end{tabular}

Food flavor is a comprehensive concept that contains sweet, sour, bitter, spicy, astringent, umami, etc. Umami is especially important for edible mushrooms because they are usually used as natural freshness-enhancing materials. Equivalent umami concentration (EUC) value calculated using an equation from sensory evaluation, based on the report of Yamaguchi et al., has often been used to evaluate umami-like taste characteristics of mushrooms [42]. For L. deliciosus, the EUC value was $145.32 \mathrm{~g}$ per $100 \mathrm{~g} \mathrm{dw}$. Mau (2005) grouped mushrooms EUC values into four levels: the first level, $>1000 \mathrm{~g}$ per $100 \mathrm{~g} \mathrm{dw}$, the second level, 100-1000 g per $100 \mathrm{~g} \mathrm{dw}$; the third level, 10-100 g per $100 \mathrm{~g} \mathrm{dw}$; and the fourth level, $<10 \mathrm{~g}$ per $100 \mathrm{~g} \mathrm{dw}$ [43]. Thus, the EUC value for L. deliciosus belonged to the second level. 


\subsection{Volatile Aroma Compounds Relating to Special Flavor}

Although mushroom tastes depend on water-soluble non-volatile compounds, the function of volatile aroma compounds could not be ignored due to the fact that they directly influence consumer acceptability. Typical volatile aroma compounds in mushrooms originated mostly from chemical or enzymatic oxidation of unsaturated fatty acids and further interactions with proteins, peptides, and free amino acids [44]. In this research, volatile aroma compounds of L. deliciosus were estimated by headspace solid phase micro-extraction GS-MS combining library catalog. As shown in Table 5 and Figure S6, 25 compounds were identified, including 15 aldehydes, six acids, two alkanes, one alcohol, and one ester. Based on qualitative and quantitative analysis, acids were confirmed to be the most important aroma volatile compounds accounting for a $84.23 \%$ total chromatographic area, followed by aldehydes with $14.77 \%$. Acids dominated in L. deliciosus aroma volatile compounds, which was in accordance with a previous study on L. edodes and Pleurotus sajor-caju conducted by Çağlarırmak [45]. However, other studies have shown that alcohols are important aromatic substances in mushrooms, which differed to our findings in the present research, this might be caused by the drying process, since Tian also found that drying leads to a sharp drop in alcohols while acids and aldehydes increase in L. edodes [44]. Moreover, volatile aroma compounds of mushrooms were also affected by growth conditions and genetic differences.

Table 5. Aroma volatile compounds of wild L. deliciosus.

\begin{tabular}{cc}
\hline Component & Composition (\%) \\
\hline Heptanal & $2.03 \pm 0.15$ \\
Benzaldehyde & $2.23 \pm 0.09$ \\
Hexanoic acid & $0.67 \pm 0.02$ \\
Octanal & $1.19 \pm 0.07$ \\
Benzyl alcohol & $0.08 \pm 0.00$ \\
2-Octenal & $0.58 \pm 0.11$ \\
Nonanal & $1.58 \pm 0.16$ \\
2-Nonenal & $0.83 \pm 0.05$ \\
Dodecane & $0.29 \pm 0.04$ \\
Decanal & $0.79 \pm 0.05$ \\
2-Decenal & $1.62 \pm 0.29$ \\
Undecanal & $0.46 \pm 0.02$ \\
2,4-Decadienal & $0.29 \pm 0.01$ \\
2-Undecenal & $1.48 \pm 0.18$ \\
2-Butyl-2-octenal & $0.16 \pm 0.02$ \\
n-Decanoic acid & $0.76 \pm 0.05$ \\
Decanoic acid, ethyl ester & $0.24 \pm 0.01$ \\
Tetradecane & $0.38 \pm 0.06$ \\
Dodecanal & $0.47 \pm 0.08$ \\
2-Dodecenal & $0.65 \pm 0.03$ \\
Tridecanal & $0.41 \pm 0.10$ \\
$n$-Hexadecanoic acid & $12.82 \pm 0.67$ \\
9-Octadecadienoic acid & $3.11 \pm 0.21$ \\
9-Octadecenoic acid & $60.57 \pm 2.89$ \\
Octadecanoic acid & $6.30 \pm 0.74$ \\
\hline
\end{tabular}

\subsection{Antioxidant Activity}

Free radicals induce cell-damage, which can cause DNA mutation, proteins damage, lipid peroxidation, and low-density lipoproteins modification. Free radicals can also cause several diseases including diabetes, cancer, neurodegenerative and cardiovascular diseases [46,47]. Usually, food or food extracts can act as antioxidant to counteract damage caused by free radicals. However, the antioxidant capacity of food is determined by complicated factors with various action mechanisms [48]. Thus, several evaluation methods are always used simultaneously to evaluate the 
antioxidant capacity of food. Due to this effect, we evaluated the antioxidant activity of L. deliciosus through DPPH and ABTS radical scavenging and ferric ion reducing (FRAP) assays using ethanol and aqueous extracts. The antioxidant capacity was expressed as trolox equivalent antioxidant capacity (TEAC) values. As shown in Table 6, the TEAC values of ethanol extracts with DPPH, ABT, S and FRAP assays were 18.38, 20.07, and $10.72 \mu \mathrm{mol}$ Trolox/g dw, respectively. For aqueous extracts, these values were $45.63,48.05$, and $22.28 \mu \mathrm{mol}$ Trolox/g dw, respectively. Aqueous extracts showed 2-3 fold higher antioxidant capacity compared to ethanol extracts, which might be related to the content of phenols in two extracts, since the total phenol content in aqueous extract was 3.01 fold higher than in ethanol extract.

Table 6. Antioxidant capacity and total phenols in ethanol and aqueous extracts obtained from wild L. deliciosus.

\begin{tabular}{|c|c|c|c|c|}
\hline & $\begin{array}{c}\text { TEAC }_{\text {DPPH }} \\
(\mu \mathrm{molTrolox} / \mathrm{g} \mathrm{dw})^{a}\end{array}$ & $\begin{array}{c}\text { TEAC }_{\text {ABTS }} \\
(\mu \mathrm{molTrolox} / \mathrm{g} \mathrm{dw})^{b}\end{array}$ & $\begin{array}{c}\text { TEAC }_{\text {FRAP }} \\
(\mu \mathrm{molTrolox} / \mathrm{g} \mathrm{dw})^{\mathrm{c}}\end{array}$ & $\begin{array}{l}\text { Total Phenols Content } \\
(\mathrm{mg} \mathrm{GAE} / \mathrm{g} \mathrm{dw})^{d}\end{array}$ \\
\hline Ethanol extract & $18.38 \pm 1.31$ & $20.07 \pm 1.75$ & $10.72 \pm 1.04$ & $4.55 \pm 0.24$ \\
\hline
\end{tabular}

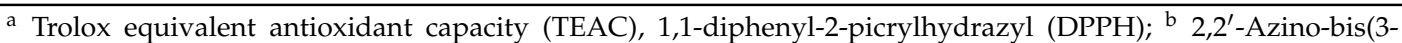
ethylbenzothiazoline-6-sulfonic acid) diammonium salt (ABTS); ${ }^{c}$ Ferric ion reducing antioxidant power (FRAP);

${ }^{\mathrm{d}}$ Gallic acid equivalent weight (GAE).

\subsection{Antihyperglycemic Activity}

$\alpha$-Amylase and $\alpha$-glucosidase are key enzymes in the digestive system that catalyze carbohydrate hydrolysis to enhance blood glucose concentration. A proportion of the population, especially diabetics, suffer from hyperglycemia. A therapeutic approach to hyperglycaemia is to retard the absorption of glucose by inhibiting carbohydrate-hydrolyzing enzymes [49]. Thus, effective and nontoxic inhibitors of $\alpha$-amylase and $\alpha$-glucosidase are crucial for the treatment of hyperglycemia. As shown in Figure 1, ethanol extracts exhibited a dose-dependent increase in both $\alpha$-amylase and $\alpha$-glucosidase inhibitory assays, while compared with acarbose, the antienzyme activity of ethanol extract was weaker. At $5.0 \mathrm{mg} / \mathrm{mL}$, ethanol extracts exhibited 29.53 and $52.36 \%$ on $\alpha$-amylase and $\alpha$-glucosidase inhibition, respectively. However, regarding aqueous extracts, no inhibitory effects on $\alpha$-amylase and $\alpha$-glucosidase were observed.
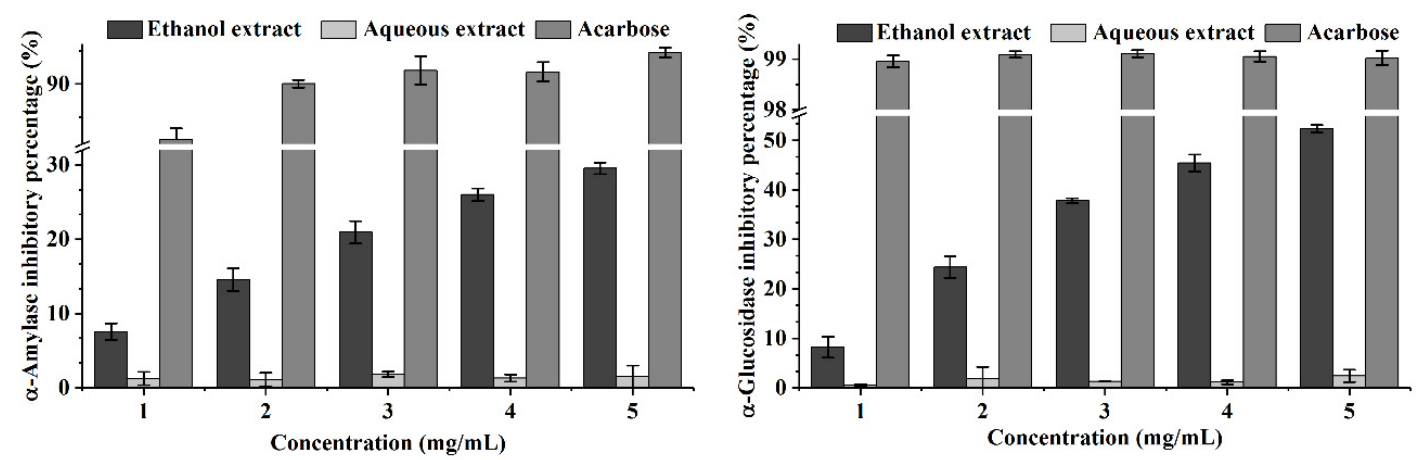

Figure 1. Antihyperglycemic activity of ethanol extract and aqueous extract obtained from wild L. deliciosus.

\section{Materials and Methods}

\subsection{Mushroom Species}

Wild growing Lactarius deliciosus fruiting bodies were collected from Dazhou (Southwest China) pine forests, in the autumn of 2016. All the samples were selected and authenticated at the Dazhou Institute of Agricultural Sciences based on their microscopic and macroscopic characteristics. 


\subsection{Standards and Reagents}

1,1-diphenyl-2-picrylhydrazyl (DPPH), 2,2'-Azino-bis(3-ethylbenzothiazoline-6-sulfonic acid) diammonium salt (ABTS) were purchased from Sigma Chemical Co. (St. Louis, MO, USA). Ferric-tripyridyltriazine ( $\mathrm{Fe}^{3+}$-TPTZ) is purchased from Beyotime Biotechnology (Shanghai, China). Chromatographic grade analytical standards asparaginic acid, glutamic acid, asparagine, serine, glutamine, histidine, glycine, threonine, citrulline, arginine, alanine, tyrosine, cystine, valine, methionine, tryptophan, phenylalanine, isoleucine, leucine, lysine, hydroxyproline, proline, $5^{\prime}-\mathrm{CMP}$, 5'-UMP, 5'-GMP, 5'-IMP, 5'-XMP, 5'-AMP, trehalose, mannitol, quininic acid, L-malic acid and fumaric acid purchased from Solarbio Science \& Technology Co., Ltd. (Beijing, China). $\alpha$-Amylase, $\alpha$-glucosidase, 4-nitrophenyl $\alpha$ - $d$-glucopyranoside (PNPG), and soluble starch were purchased from Shanghai Yuanye Bio-Technology Co., Ltd. (Shanghai, China). All other reagents were analytical grade and obtained from Chengdu Kelong Chemical Factory (Chengdu, China).

\subsection{Nutritional Value Assay}

Moisture, ash, crude fat, crude proteins, and dietary fiber of the research sample were analyzed by the Association of Official Analytical Chemists methods [50]. Briefly, moisture content was measured by hot air heating at $105{ }^{\circ} \mathrm{C}$ until constant weight; ash content was measured by calcination at $600 \pm 15^{\circ} \mathrm{C}$ using a muffle furnace; crude fat was measured by Soxhlet extraction method with petroleum; crude protein content was estimated by the macro-Kjeldahl method using convert coefficient as 4.38; dietary fiber content was estimated by enzymatic hydrolysis method. Total carbohydrate content was measured by the phenol-sulfuric acid method after test sample completely hydrolyzed by hydrochloric acid. Total energy contribution was calculated according to the following equation [40]:

$$
\text { Energy }(k c a l)=4 \times(g \text { proteins }+g \text { carbohydrate })+9 \times(g \text { fat })
$$

\subsection{Fatty Acids Composition Assay}

Fatty acids composition of crude fat was measured by GC-MS method. Briefly, $20 \mathrm{mg}$ crude fat was methylated with $1 \mathrm{~mL}$ of sodium hydroxide $(1 \mathrm{M})$ methanol solution. Then, $2 \mathrm{~mL} n$-hexane was added to the mixture. Finally, the $n$-hexane phase was filtered through a $0.22-\mu \mathrm{m}$ membrane filter before GC-MS analysis. The chromatographic analysis was performed on an Agilent 7890B-5977A GC-MS system equipped with an HP-5MS column $(30 \mathrm{~m} \times 0.25 \mathrm{~mm} \times 0.25 \mu \mathrm{m})$. Helium was used as carrier gas at the flow rate of $1 \mathrm{~mL} / \mathrm{min}$. The injection volume was $1.0 \mu \mathrm{L}$ with a split ratio of 1:50 at $250{ }^{\circ} \mathrm{C}$. The column temperature was programmed as follow: initial temperature at $50{ }^{\circ} \mathrm{C}$ (held for $1 \mathrm{~min}$ ), increased to $160^{\circ} \mathrm{C}$ at $20^{\circ} \mathrm{C} / \mathrm{min}$ (held for $1 \mathrm{~min}$ ), increased to $200^{\circ} \mathrm{C}$ at $20^{\circ} \mathrm{C} / \mathrm{min}$ (held for $1 \mathrm{~min}$ ), increased to $250^{\circ} \mathrm{C}$ at $5{ }^{\circ} \mathrm{C} / \mathrm{min}$ (held for $5 \mathrm{~min}$ ). Mass spectrometry conditions: interface temperature $250{ }^{\circ} \mathrm{C}$, ion source temperature $230{ }^{\circ} \mathrm{C}$, MS quadrupoles temperature $150{ }^{\circ} \mathrm{C}$, electron energy $70 \mathrm{eV}$, and $\mathrm{m} / \mathrm{z}$ scanned area $35-550$.

\subsection{Metal Elements Assay}

Metal elements of $L$. deliciosus were analyzed by ICP-MS method. Briefly, $0.2 \mathrm{~g}$ lyophilized sample powder was put into digestion tank, $5 \mathrm{~mL} \mathrm{HNO}_{3}$ was added and fully digested in a Multiwave Pro microwave digester (Anton Paar $\mathrm{GmbH}$, Graz, Austria). Then, excess acid was expelled under $150{ }^{\circ} \mathrm{C}$, and residual liquid was diluted with deionized water to $25 \mathrm{~mL}$. Finally, metal elements analysis was performed on a PerkinElmer NexION350D system (PerkinElmer Co., Waltham, MA, USA). The working parameters were as following: Radio-frequency power $1500 \mathrm{~W}$, nebulizer flow rate $0.8 \mathrm{~L} / \mathrm{min}$, coolant gas flow $15 \mathrm{~L} / \mathrm{min}$, scanning mode peak hopping, sampling depth 10 , and isotopes of selected ${ }^{24} \mathrm{Mg}^{+},{ }^{43} \mathrm{Ca}^{+},{ }^{53} \mathrm{Cr}^{+},{ }^{55} \mathrm{Mn}^{+},{ }^{57} \mathrm{Fe}^{+},{ }^{63} \mathrm{Cu}^{+},{ }^{66} \mathrm{Zn}^{+},{ }^{75} \mathrm{As}^{+},{ }^{111} \mathrm{Cd}^{+},{ }^{208} \mathrm{~Pb}^{+}$. 


\subsection{Free Sugars and Free Amino Acids Assay}

Free sugars and free amino acids were analyzed according to previous methods $[23,36]$ with slight modification. Briefly, $0.2 \mathrm{~g}$ lyophilized sample powder was suspended in $20 \mathrm{~mL}$ aqueous ethanol $(80 \%, v / v)$, and extracted $30 \mathrm{~min}$ at $80^{\circ} \mathrm{C}$. The clear supernatant was obtained through centrifuging at $10,000 \times g$ for $10 \mathrm{~min}$. The above extraction process repeated again, and supernatant was collected together. Then, the supernatant was analyzed by an Agilent 1260 HPLC system equipped with a Hi-Plex Ca column $(300 \times 7.7 \mathrm{~mm}, 8.0 \mu \mathrm{m})$ and a Refractive Index Detector (RID) for free sugars assay. The analysis conditions of free sugars were as follows: injection volume: $5 \mu \mathrm{L}$; mobile phase: $\mathrm{H}_{2} \mathrm{O}$; flow rate of mobile phase: $0.5 \mathrm{~mL} / \mathrm{min}$; column temperature: $80^{\circ} \mathrm{C}$; detector temperature: $40^{\circ} \mathrm{C}$. Furthermore, free amino acids were analyzed by HPLC equipped with a Zorbax Eclipse AAA column $(150 \times 4.6 \mathrm{~mm}, 5.0 \mu \mathrm{m})$ and a Fluorescence Detector (FLD) (Agilent Technologies, Inc., Santa Clara, CA, USA) using above supernatant by online pre-column derivatization high performance liquid chromatography that has been detailed reported by Sun et al. [36].

\subsection{Flavor 5'-Nucleotides Assay}

Flavor $5^{\prime}$-nucleotides were analyzed according to the previous method [51] with slight modification. Briefly, $0.5 \mathrm{~g}$ lyophilized sample powder was mixed with $20 \mathrm{~mL}$ distilled water and extracted by boiling water bath for $1 \mathrm{~min}$. Then, the clear supernatant was obtained through centrifuging at $10,000 \times g$ for $10 \mathrm{~min}$. The above extraction process repeated again, and the supernatant was collected together. Finally, flavor $5^{\prime}$-nucleotides were analyzed by HPLC equipped with a Zorbax SB-C18 column $(150 \times 4.6 \mathrm{~mm}, 5.0 \mu \mathrm{m})$ and a Diode Array Detector (DAD) (Agilent Technologies, Inc., Santa Clara, CA, USA) using above supernatant. The analysis conditions were as follows: injection volume: $10 \mu \mathrm{L}$; mobile phase $\mathrm{A}$ : $\mathrm{H}_{2} \mathrm{O}$; mobile phase $\mathrm{B}$ : $0.01 \mathrm{M} \mathrm{KH}_{2} \mathrm{PO}_{4}(\mathrm{pH}=4.0$; containing $1.45 \mathrm{M}$ tetrabutylammonium hydrogen sulfate); mobile phase $\mathrm{C}$ : Acetonitrile; mobile phase gradient: 80-80-77-77\% of mobile phase B and 3-3-6-6\% of mobile phase $C$ along with analysis time linear increased from 0-9.5-13-15 min; flow rate of mobile phase: $1.0 \mathrm{~mL} / \mathrm{min}$; column temperature: $25^{\circ} \mathrm{C}$; detector wavelength: $254 \mathrm{~nm}$.

\subsection{Organic Acids Assay}

Organic acids were analyzed by SPE-HPLC method. Briefly, $0.15 \mathrm{~g}$ lyophilized sample powder was extracted twice by $20 \mathrm{~mL}$ methanol at $40{ }^{\circ} \mathrm{C}$ for $30 \mathrm{~min}$. The supernatant was collected through centrifugation and dried under negative pressure condition. Then, the residue was re-dissolved by $1 \mathrm{~mL}$ distilled water and purified by SAX solid phase extraction column. Finally, the purified liquid was diluted to $100 \mathrm{~mL}$ and analyzed by HPLC equipped with a Zorbax SB-C18 column $(150 \times 4.6 \mathrm{~mm}$, $5.0 \mu \mathrm{m}$ ) and a Diode Array Detector. The analysis conditions were as follows: injection volume: $10 \mu \mathrm{L}$; mobile phase A: $0.1 \%$ phosphoric acid solution; mobile phase B: methanol; mobile phase ratio: mobile phase A: mobile phase $\mathrm{A}=97.5: 2.5$; flow rate of mobile phase: $1.0 \mathrm{~mL} / \mathrm{min}$; column temperature: $40{ }^{\circ} \mathrm{C}$; detector wavelength: $210 \mathrm{~nm}$.

\subsection{Equivalent Umami Concentration}

The equivalent umami concentration (EUC, g monosodium glutamate (MSG) per $100 \mathrm{~g}$ ) was used to reflect the umami intensity of L. deliciosus, and is represented by the following addition equation according to Yamaguchi report [42].

$$
Y=\sum a_{i} b_{i}+1218\left(\sum a_{i} b_{i}\right)\left(\sum a_{j} b_{j}\right)
$$

where $Y$ is the EUC of the mixture in terms of $\mathrm{g}$ MSG $/ 100 \mathrm{~g} ; a_{i}$ is the concentration (g per $100 \mathrm{~g} \mathrm{dw}$ ) of each umami amino acid (aspartic acid or glutamic acid); $a_{j}$ is the concentration (g per $100 \mathrm{~g} \mathrm{dw}$ ) of each umami $5^{\prime}$-nucleotide (5'-IMP, $5^{\prime}$-GMP, $5^{\prime}$-XMP or $5^{\prime}$-AMP); $b_{i}$ is the relative umami concentration for each umami amino acid to MSG (aspartic acid, 0.077 ; glutamic acid, 1 ); $b_{j}$ is the relative umami 
concentration for umami $5^{\prime}$-nucelotide to $5^{\prime}$-IMP (5'-IMP, 1 ; $5^{\prime}$-GMP, 2.3; $5^{\prime}$-XMP, 0.61; 5'-AMP, 0.18); and 1218 is a synergistic constant based on the concentration $\mathrm{g}$ per $100 \mathrm{~g}$ used.

\subsection{Volatile Aroma Components Assay}

Volatile aroma components were analyzed using the headspace SPME-GC-MS method. Briefly, $2.0 \mathrm{~g}$ lyophilized sample powder was put into a sample bottle, a polydimethylsiloxane SPME fiber $\left(100 \mu \mathrm{m}\right.$, Supelco, Bellefonte PA) was used to adsorb statically for $40 \mathrm{~min}$ at $50^{\circ} \mathrm{C}$. Then, the volatile aroma components were released at $250^{\circ} \mathrm{C}$ and analyzed on an Agilent 7890B-5977C GC-MS system equipped with DB-5MS column $(30 \mathrm{~m} \times 0.25 \mathrm{~mm} \times 0.25 \mu \mathrm{m})$. Helium was used as carrier gas at the flow rate of $1 \mathrm{~mL} / \mathrm{min}$. The column temperature was programmed as follow: initial temperature at $40{ }^{\circ} \mathrm{C}$ (held for $1 \mathrm{~min}$ ), increased to $70{ }^{\circ} \mathrm{C}$ at $10{ }^{\circ} \mathrm{C} / \mathrm{min}$ (held for $2 \mathrm{~min}$ ), increased to $105^{\circ} \mathrm{C}$ at $3{ }^{\circ} \mathrm{C} / \mathrm{min}$ (held for $1 \mathrm{~min}$ ), increased to $180^{\circ} \mathrm{C}$ at $5{ }^{\circ} \mathrm{C} / \mathrm{min}$ (held for $1 \mathrm{~min}$ ), increased to $220^{\circ} \mathrm{C}$ at $10^{\circ} \mathrm{C} / \mathrm{min}$ (held for $5 \mathrm{~min}$ ). Mass spectrometry conditions: interface temperature $280^{\circ} \mathrm{C}$, ion source temperature $230{ }^{\circ} \mathrm{C}$, MS quadrupoles temperature $150{ }^{\circ} \mathrm{C}$, electron energy $70 \mathrm{eV}$, and $\mathrm{m} / z$ scanned area $35-550$.

\subsection{Ethanol and Aqueous Extracts Preparation}

The lyophilized sample was extracted with ethanol at $50{ }^{\circ} \mathrm{C}$ for $1 \mathrm{~h}$ three times, the supernatant was collected, concentrated and dried to obtain ethanol extracts. Then, the residue was extracted with distilled water at $80^{\circ} \mathrm{C}$ for $1 \mathrm{~h}$ three times to obtain aqueous extract.

\subsection{Antioxidant Activity Assay}

\subsubsection{DPPH Radical Scavenging Activity Assay}

DPPH radical scavenging activity was measured according to the previous method described in [52] with slight modification. Briefly, $70 \mu \mathrm{L}$ sample solution was mixed with $140 \mu \mathrm{L}$ DPPH-ethanol solution. Then, the mixture was incubated in the dark for $30 \mathrm{~min}$ at room temperature, and the absorbance at $517 \mathrm{~nm}$ was measured using a spectrophotometric micro-plate reader. Trolox solution was used as a positive control and the antioxidant properties of samples were expressed as $\mu$ mol trolox per g dry weight extract ( $\mu$ mol Trolox/g dw).

\subsubsection{ABTS Radical Scavenging Activity Assay}

ABTS radical scavenging activity was measured according to previous method described in [53] with slight modification. Briefly, $100 \mu \mathrm{L}$ sample solution was mixed with $100 \mu \mathrm{L}$ ABTS solution. Then, the mixture was incubated in the dark for $6 \mathrm{~min}$ at room temperature, and the absorbance at $734 \mathrm{~nm}$ was measured. Trolox solution was used as a positive control and the antioxidant properties of samples were expressed as $\mu \mathrm{mol}$ trolox per $\mathrm{g}$ dry weight extract ( $\mu \mathrm{mol}$ Trolox/g dw).

\subsubsection{Ferric Ion Reducing Activity Assay}

Ferric ion reducing activity was measured according to previous method described in [54] with slight modification. Briefly, $100 \mu \mathrm{L}$ sample solution was mixed with $100 \mu \mathrm{L}$ Ferric-tripyridyltriazine $\left(\mathrm{Fe}^{3+}\right.$-TPTZ) solution. Then, the mixture was incubated in the dark for $10 \mathrm{~min}$ at room temperature, and the absorbance at $593 \mathrm{~nm}$ was measured. Trolox solution was used as a positive control and the antioxidant properties of samples were expressed as $\mu \mathrm{mol}$ trolox per $\mathrm{g}$ dry weight extract $(\mu \mathrm{mol}$ Trolox/g dw).

\subsubsection{Total Polyphenols Content Assay}

Total polyphenols contents of ethanol and aqueous extracts were determined by the Folin-Ciocalteu assay [55] with some modifications. Briefly, $1 \mathrm{~mL}$ sample solution was mixed with $2 \mathrm{~mL}$ Folin-Ciocalteu reagent. After incubated for two minutes, $2 \mathrm{~mL} \mathrm{Na}{ }_{2} \mathrm{CO}_{3}(10 \%, w / v)$ was added 
and the resulting mixture was incubated for $15 \mathrm{~min}$ at $50{ }^{\circ} \mathrm{C}$. Finally, absorbance at $775 \mathrm{~nm}$ was measured and polyphenol contents was expressed as mg gallic acid equivalents per $\mathrm{g}$ dry weight extract (mg GAE/g dw).

\subsection{Antihypertensive Activity Assay}

\subsection{1. $\alpha$-Amylase Inhibition Activity Assay}

$\alpha$-Amylase inhibition activity was carried out according to previous method [56] with slight modification. Briefly, $\alpha$-amylase $(1 \mathrm{U} / \mathrm{mL})$, soluble starch $(1 \%)$ and a series concentration of sample were dissolved by $0.02 \mathrm{M}$ sodium phosphate buffer $(\mathrm{pH}=6.9$, containing $0.0067 \mathrm{M}$ sodium chloride). Sample solution $(100 \mu \mathrm{L})$ and $100 \mu \mathrm{L} \alpha$-amylase solution were mixed and incubated at $37^{\circ} \mathrm{C}$ for $10 \mathrm{~min}$. After adding $500 \mu \mathrm{L}$ soluble starch solution, the mixture was incubated at $37^{\circ} \mathrm{C}$ for $10 \mathrm{~min}$. Then, the reaction was terminated by $100 \mu \mathrm{L}$ hydrochloric acid solution $(5 \mathrm{M})$. After diluting above mixture six times with distilled water, $50 \mu \mathrm{L}$ liquid was taken, added into 96-well plate, and $150 \mu \mathrm{L}$ of iodine solution was added as color developing reagent. The absorbance at $660 \mathrm{~nm}$ was measured using a spectrophotometric micro-plate reader. Finally, the $\alpha$-amylase inhibition activity was calculated as the following formula:

$$
\alpha-\text { Amylase inhibition activity }(\%)=\frac{A b s_{1}}{A b s_{2}} \times 100
$$

where $A b s_{1}$ was the absorbance of sample solution mixed with $\alpha$-amylase solution and soluble starch solution; and $A b s_{2}$ was the absorbance of sample solution mixed with soluble starch solution ( $\alpha$-amylase solution was replaced by sodium phosphate buffer).

\subsection{2. $\alpha$-Glucosidase Inhibition Activity Assay}

$\alpha$-Glucosidase inhibition activity was carried out according to previous method described in [57] with slight modification. Briefly, $\alpha$-glucosidase $(0.5 \mathrm{U} / \mathrm{mL})$, 4-nitrophenyl $\alpha$-d-glucopyranoside (PNPG, $3 \mathrm{mM}$ ) a series concentration of sample were dissolved by $0.1 \mathrm{M}$ sodium phosphate buffer $(\mathrm{pH}=6.8)$. Sample solution $(100 \mu \mathrm{L})$ and $100 \mu \mathrm{L} \alpha$-glucosidase solution were mixed and incubated at $37^{\circ} \mathrm{C}$ for $10 \mathrm{~min}$. After adding $100 \mu \mathrm{L}$ PNPG solution, the mixture was incubated at $37^{\circ} \mathrm{C}$ for $10 \mathrm{~min}$. Then, the reaction was terminated by $300 \mu \mathrm{L}$ sodium carbonate solution $(0.2 \mathrm{M})$. Finally, the absorbance at $405 \mathrm{~nm}$ was measured using a spectrophotometric micro-plate reader, and the $\alpha$-glucosidase inhibition activity was calculated as the following formula:

$$
\alpha-\text { Glu cosidase inhibition activity }(\%)=\left[1-\frac{\left(A b s_{1}-A b s_{2}\right)}{A b s_{0}}\right] \times 100
$$

where $A b s_{0}$ was the absorbance of the $\alpha$-glucosidase solution mixed with PNPG solution; $A b s_{1}$ was the absorbance of sample solution mixed with $\alpha$-glucosidase solution and PNPG solution; and $A b s_{2}$ was the absorbance of sample solution mixed with PNPG solution ( $\alpha$-glucosidase solution was replaced by sodium phosphate buffer).

\subsection{Statistical Analysis}

All assays were carried out in triplicate, and the results are expressed as mean \pm standard deviation (SD).

\section{Conclusions}

In conclusion, chemical analysis, GC-MS, ICP-MS, HPLC, SPE-HPLC, HS-SPME-GC-MS, radicals scavenging assays, ferric ion reducing activity assay, and enzymes inhibitory assays were conducted to evaluate nutritional value, non-volatile flavor compounds, volatile aroma compounds, potential 
antioxidant and anti-hyperglycemic activities of wild mushroom L. deliciosus from China for the first time. Experimental data indicated that L. deliciosus is a good wild edible mushroom with high nutritional value, low calorie level, and extensive flavor compounds. Moreover, L. deliciosus also have potential as natural antioxidant and anti-hyperglycemic agents in food and pharmaceutical industry in the future.

Supplementary Materials: The following are available online, Figure S1: Gas chromatography mass spectrum of fatty acids of L. deliciosus fat; Figure S2: High performance liquid chromatography of amino acids analyzed by online OPA-FMOC derivation; Figure S3: High performance liquid chromatography of flavor 5'-nucleotides; Figure S4: High performance liquid chromatography of organic acids; Figure S5: High performance liquid chromatography of free sugars; and Figure S6: Headspace solid phase micro-extraction gas chromatography mass spectrum of aroma volatile compounds from L. deliciosus.

Author Contributions: Z.X. and C.D. designed the research; Z.X., L.F., S.F. and M.Y. performed the experiments; Z.X., L.F., Y.H., J.L., L.Z. and H.Y. analyzed the data and wrote the draft manuscript; and C.D. provided financial support. All authors revised the manuscript.

Funding: This research received no external funding.

Conflicts of Interest: The authors declare no conflict of interest.

\section{References}

1. Okoro, I.O. Antioxidant activities and phenolic contents of three mushroom species, Lentinus squarrosulus Mont. Volvariella esculenta (Massee) Singer and Pleurocybella porrigens (Pers.) Singer. Int. J. Nutr. Metab. 2012, $4,72-76$.

2. Ouzouni, P.K.; Petridis, D.; Koller, W.D.; Riganakos, K.A. Nutritional value and metal content of wild edible mushrooms collected from West Macedonia and Epirus, Greece. Food Chem. 2009, 115, 1575-1580. [CrossRef]

3. Finimundy, T.C.; Dillon, A.J.P.; Henriques, J.A.P.; Ely, M.R. A review on general nutritional compounds and pharmacological properties of the Lentinula edodes mushroom. Food Nutr. Sci. 2014, 5, 1095-1105.

4. Reis, F.S.; Barros, L.; Martins, A.; Ferreira, I.C.F.R. Chemical composition and nutritional value of the most widely appreciated cultivated mushrooms: An inter-species comparative study. Food Chem. Toxicol. 2012, 50, 191-197. [CrossRef] [PubMed]

5. Miles, P.G.; Chang, S.T. Mushrooms: Cultivation, Nutritional Value, Medicinal Effect, and Environmental Impact, 2nd ed.; CRC Press: Boca Raton, FL, USA, 2004.

6. Culleré, L.; Ferreira, V.; Chevret, B.; Venturini, M.E.; Sánchez-Gimeno, A.C.; Blanco, D. Characterisation of aroma active compounds in black truffles (Tuber melanosporum) and summer truffles (Tuber aestivum) by gas chromatography-olfactometry. Food Chem. 2010, 122, 300-306. [CrossRef]

7. Cho, I.H.; Namgung, H.J.; Choi, H.K.; Kim, Y.S. Volatiles and key odorants in the pileus and stipe of pine-mushroom (Tricholoma matsutake Sing.). Food Chem. 2008, 106, 71-76. [CrossRef]

8. Mizuno, T. Bioactive biomolecules of mushrooms: Food function and medicinal effect of mushroom fungi. Food Rev. Int. 1995, 11, 5-21. [CrossRef]

9. Verbeken, A.; Nuytinck, J. Not every milkcap is a Lactarius. Scr. Bot. Belg. 2013, 51, 162-168.

10. Feussi Tala, M.; Qin, J.; Ndongo, J.T.; Laatsch, H. New azulene-type sesquiterpenoids from the fruiting bodies of Lactarius deliciosus. Nat. Prod. Bioprospect. 2017, 7, 269-273. [CrossRef]

11. Anke, H.; Bergendorff, O.; Sterner, O. Assays of the biological activities of guaiane sesquiterpenoids isolated from the fruit bodies of edible lactarius species. Food Chem. Toxicol. 1989, 27, 393-397. [CrossRef]

12. Bergendorff, O.; Sterner, O. The sesquiterpenes of Lactarius deliciosus and Lactarius deterrimus. Phytochemistry 1988, 27, 97-100. [CrossRef]

13. Ding, X.; Hou, Y.; Hou, W. Structure feature and antitumor activity of a novel polysaccharide isolated from Lactarius deliciosus Gray. Carbohyd. Polym. 2012, 89, 397-402. [CrossRef]

14. Hou, Y.; Liu, L.; Ding, X.; Zhao, D.; Hou, W. Structure elucidation, proliferation effect on macrophage and its mechanism of a new heteropolysaccharide from Lactarius deliciosus Gray. Carbohyd. Polym. 2016, 152, 648-657. [CrossRef]

15. Vetter, J. Trypsin inhibitor activity of basidiomycetous mushrooms. Eur. Food Res. Technol. 2000, 211, 346-348. [CrossRef] 
16. Kosanić, M.; Ranković, B.; Rančić, A.; Stanojković, T. Evaluation of metal concentration and antioxidant, antimicrobial, and anticancer potentials of two edible mushrooms Lactarius deliciosus and Macrolepiota procera. J. Food Drug Anal. 2016, 24, 477-484. [CrossRef]

17. Moro, C.; Palacios, I.; Lozano, M.; D’Arrigo, M.; Guillamón, E.; Villares, A.; Martínez, J.A.; García-Lafuente, A. Anti-inflammatory activity of methanolic extracts from edible mushrooms in LPS activated RAW 264.7 macrophages. Food Chem. 2012, 130, 350-355. [CrossRef]

18. Rathore, H.; Prasad, S.; Sharma, S. Mushroom nutraceuticals for improved nutrition and better human health: A review. Pharma Nutr. 2017, 5, 35-46. [CrossRef]

19. Miyazawa, M.; Takahashi, T.; Horibe, I.; Ishikawa, R. Two new aromatic compounds and a new D-arabinitol ester from the mushroom Hericium erinaceum. Tetrahedron 2012, 68, 2007-2010. [CrossRef]

20. Myrdal Miller, A.; Mills, K.; Wong, T.; Drescher, G.; Lee, S.; Sirimuangmoon, C.; Schaefer, S.; Langstaff, S.; Minor, B.; Guinard, J.X. Flavor-enhancing properties of mushrooms in meat-based dishes in which sodium has been reduced and meat has been partially substituted with mushrooms. J. Food Sci. 2014, 79, S1795-S1804. [CrossRef]

21. Beluhan, S.; Ranogajec, A. Chemical composition and non-volatile components of Croatian wild edible mushrooms. Food Chem. 2011, 124, 1076-1082. [CrossRef]

22. Wang, X.M.; Zhang, J.; Wu, L.H.; Zhao, Y.L.; Li, T.; Li, J.Q.; Wang, Y.Z.; Liu, H.G. A mini-review of chemical composition and nutritional value of edible wild-grown mushroom from China. Food Chem. 2014, 151, 279-285. [CrossRef]

23. Barros, L.; Baptista, P.; Correia, D.M.; Casal, S.; Oliveira, B.; Ferreira, I.C.F.R. Fatty acid and sugar compositions, and nutritional value of five wild edible mushrooms from Northeast Portugal. Food Chem. 2007, 105, 140-145. [CrossRef]

24. Yilmaz, N.; Solmaz, M.; Türkekul, İ.; Elmastaş, M. Fatty acid composition in some wild edible mushrooms growing in the middle Black Sea region of Turkey. Food Chem. 2006, 99, 168-174. [CrossRef]

25. Orsavova, J.; Misurcova, L.; Ambrozova, J.; Vicha, R.; Mlcek, J. Fatty acids composition of vegetable oils and its contribution to dietary energy intake and dependence of cardiovascular mortality on dietary intake of fatty acids. Int. J. Mol. Sci. 2015, 16, 12871-12890. [CrossRef]

26. Calder, P.C. Functional roles of fatty acids and their effects on human health. J. Parenter. Enter. 2015, 39, 18S-32S. [CrossRef]

27. Ouzouni, P.K.; Veltsistas, P.G.; Paleologos, E.K.; Riganakos, K.A. Determination of metal content in wild edible mushroom species from regions of Greece. J. Food Compos. Anal. 2007, 20, 480-486. [CrossRef]

28. Kalač, P. Chemical composition and nutritional value of European species of wild growing mushrooms: A review. Food Chem. 2009, 113, 9-16. [CrossRef]

29. Çayır, A.; Coşkun, M.; Coşkun, M. The heavy metal content of wild edible mushroom samples collected in Canakkale province, Turkey. Biol. Trace Elem. Res. 2010, 134, 212-219. [CrossRef]

30. Mendil, D.; Uluözlü, Ö. D.; Hasdemir, E.; Çağlar, A. Determination of trace elements on some wild edible mushroom samples from Kastamonu, Turkey. Food Chem. 2004, 88, 281-285. [CrossRef]

31. Kalač, P.; Svoboda, L. A review of trace element concentrations in edible mushrooms. Food Chem. 2000, 69, 273-281. [CrossRef]

32. Food and Nutrition Board; Institute of Medicine. Dietary Reference Intakes for Calcium, Phosphorus, Magnesium, Vitamin D, and Fluoride; National Academy Press: Washington, DC, USA, 1997.

33. Trumbo, P.; Yates, A.A.; Schlicker, S.; Poos, M. Dietary reference intakes: Vitamin A, vitamin K, arsenic, boron, chromium, copper, iodine, iron, manganese, molybdenum, nickel, silicon, vanadium, and zinc. J. Acad. Nutr. Diet. 2001, 101, 294-301.

34. Pei, F.; Shi, Y.; Gao, X.; Wu, F.; Mariga, A.M.; Yang, W.; Zhao, L.; An, X.; Xin, Z.; Yang, F.; Hu, Q. Changes in non-volatile taste components of button mushroom (Agaricus bisporus) during different stages of freeze drying and freeze drying combined with microwave vacuum drying. Food Chem. 2014, 165, 547-554. [CrossRef] [PubMed]

35. Yin, C.; Fan, X.; Fan, Z.; Shi, D.; Yao, F.; Gao, H. Comparison of non-volatile and volatile flavor compounds in six Pleurotus mushrooms. J. Sci. Food Agric. 2018. [CrossRef] [PubMed] 
36. Sun, L.; Liu, Q.; Bao, C.; Fan, J. Comparison of free total amino acid compositions and their functional classifications in 13 wild edible mushrooms. Molecules 2017, 22, 350. [CrossRef] [PubMed]

37. Yang, J.H.; Lin, H.C.; Mau, J.L. Non-volatile taste components of several commercial mushrooms. Food Chem. 2001, 72, 465-471. [CrossRef]

38. Vieira, V.; Barros, L.; Martins, A.; Ferreira, I. Nutritional and biochemical profiling of Leucopaxillus candidus (Bres.) Singer wild mushroom. Molecules 2016, 21, 99. [CrossRef]

39. Mocan, A.; Fernandes, A.; Barros, L.; Crisan, G.; Smiljkovic, M.; Sokovic, M.; Ferreira, I. Chemical composition and bioactive properties of the wild mushroom Polyporus squamosus (Huds.) Fr: A study with samples from Romania. Food Funct. 2018, 9, 160-170. [CrossRef]

40. Toledo, C.V.; Barroetaveña, C.; Fernandes, Â.; Barros, L.; Ferreira, I.C.F.R. Chemical and antioxidant properties of wild edible mushrooms from native Nothofagus spp. forest, Argentina. Molecules 2016, 21, 1201. [CrossRef]

41. Barros, L.; Pereira, C.; Ferreira, I.C.F.R. Optimized analysis of organic acids in edible mushrooms from Portugal by ultra fast liquid chromatography and photodiode array detection. Food Anal. Method. 2013, 6, 309-316. [CrossRef]

42. Yamaguchi, S.; Yoshikawa, T.; Ikeda, S.; Ninomiya, T. Measurement of the relative taste intensity of some L- $\alpha$-amino acids and 5'-nucleotides. J. Food Sci. 1971, 36, 846-849. [CrossRef]

43. Mau, J. The umami taste of edible and medicinal mushrooms. Int. J. Med. Mushrooms 2005, 7, 119-126. [CrossRef]

44. Tian, Y.; Zhao, Y.; Huang, J.; Zeng, H.; Zheng, B. Effects of different drying methods on the product quality and volatile compounds of whole shiitake mushrooms. Food Chem. 2016, 197, 714-722. [CrossRef]

45. Çağlarırmak, N. The nutrients of exotic mushrooms (Lentinula edodes and Pleurotus species) and an estimated approach to the volatile compounds. Food Chem. 2007, 105, 1188-1194. [CrossRef]

46. Ziegler, D.V.; Wiley, C.D.; Velarde, M.C. Mitochondrial effectors of cellular senescence: Beyond the free radical theory of aging. Aging cell 2015, 14,1-7. [CrossRef] [PubMed]

47. Liochev, S.I. Reactive oxygen species and the free radical theory of aging. Free Radic. Biol. Med. 2013, 60, 1-4. [CrossRef] [PubMed]

48. Moo-Huchin, V.M.; Moo-Huchin, M.I.; Estrada-León, R.J.; Cuevas-Glory, L.; Estrada-Mota, I.A.; Ortiz-Vázquez, E.; Betancur-Ancona, D.; Sauri-Duch, E. Antioxidant compounds, antioxidant activity and phenolic content in peel from three tropical fruits from Yucatan, Mexico. Food Chem. 2015, 166, 17-22. [CrossRef]

49. Bhandari, M.R.; Jong-Anurakkun, N.; Hong, G.; Kawabata, J. $\alpha$-Glucosidase and $\alpha$-amylase inhibitory activities of Nepalese medicinal herb Pakhanbhed (Bergenia ciliata, Haw.). Food Chem. 2008, 106, 247-252. [CrossRef]

50. Hasan, M.T. Official Methods of Analysis, 15th ed.; Association of Official Analytical Chemists: Artington, VR, USA, 2015.

51. Sommer, I.; Schwartz, H.; Solar, S.; Sontag, G. Effect of gamma-irradiation on flavour 5'-nucleotides, tyrosine, and phenylalanine in mushrooms (Agaricus bisporus). Food Chem. 2010, 123, 171-174. [CrossRef]

52. Xiang, C.; Xu, Z.; Liu, J.; Li, T.; Yang, Z.; Ding, C. Quality, composition, and antioxidant activity of virgin olive oil from introduced varieties at Liangshan. LWT Food Sci. Technol. 2017, 78, 226-234. [CrossRef]

53. Li, X.; Lin, J.; Gao, Y.; Han, W.; Chen, D. Antioxidant activity and mechanism of Rhizoma Cimicifugae. Chem. Cent. J. 2012, 6, 140. [CrossRef]

54. Xia, Q.; Wang, L.; Xu, C.; Mei, J.; Li, Y. Effects of germination and high hydrostatic pressure processing on mineral elements, amino acids and antioxidants in vitro bioaccessibility, as well as starch digestibility in brown rice (Oryza sativa L.). Food Chem. 2017, 214, 533-542. [CrossRef] [PubMed]

55. Liu, K.; Xiao, X.; Wang, J.; Chen, C.Y.O.; Hu, H. Polyphenolic composition and antioxidant, antiproliferative, and antimicrobial activities of mushroom Inonotus sanghuang. LWT Food Sci. Technol. 2017, 82, 154-161. [CrossRef]

56. He, M.; Zeng, J.; Zhai, L.; Liu, Y.; Wu, H.; Zhang, R.; Li, Z.; Xia, E. Effect of in vitro simulated gastrointestinal digestion on polyphenol and polysaccharide content and their biological activities among 22 fruit juices. Food Res. Int. 2017, 102, 156-162. [CrossRef] [PubMed] 
57. Hemalatha, P.; Bomzan, D.P.; Sathyendra Rao, B.V.; Sreerama, Y.N. Distribution of phenolic antioxidants in whole and milled fractions of quinoa and their inhibitory effects on $\alpha$-amylase and $\alpha$-glucosidase activities. Food Chem. 2016, 199, 330-338. [CrossRef]

Sample Availability: Lyophilized powder of L. deliciosus is available from the authors.

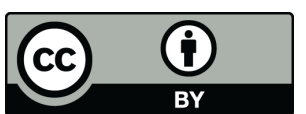

(C) 2019 by the authors. Licensee MDPI, Basel, Switzerland. This article is an open access article distributed under the terms and conditions of the Creative Commons Attribution (CC BY) license (http:/ / creativecommons.org/licenses/by/4.0/). 